\title{
Belt and Road Initiative: Catalyst for the Central Asian Integration?
}

\author{
Noor Halimah Anjani \\ Undergraduate Student of International Relations Department at Universitas Katolik Parahyangan \\ halimaahanjani@gmail.com
}

\begin{abstract}
Belt and Road Initiative (BRI) merupakan strategi pembangunan yang dikeluarkan oleh Pemerintah Tiongkok. BRI fokus membangun kerja sama dan konektivitas antara negara-negara di Eurasia. Asia Tengah merupakan salah satu kawasan yang dilewati oleh pembangunan BRI. Permasalahan ekonomi dan pembangunan menjadi alasan mengapa negara-negara ini antusias dengan adanya BRI. Namun, selain masalah ekonomi dan pembangunan, terdapat masalah lain seperti kurang baiknya hubungan antarnegara di kawasan. Pasca runtuhnya Uni Soviet, negara-negara di Asia Tengah mengalami gejolak sosial dan ekonomi. Politik isolasi pun dilakukan oleh negaranegara tersebut dengan anggapan bahwa hal tersebut merupakan cara terbaik untuk menghindari perluasan masalah terlepas dari keberadaan organisasi-organisasi kawasan di Asia Tengah. Penulis melihat terbatasnya integrasi regional sebagai salah satu alasan mengapa stabilitas kawasan di Asia Tengah sulit tercapai. Paper ini bertujuan untuk meneliti sejauh mana BRI mampu menjadi katalis bagi negara-negara Asia Tengah untuk meningkatkan kerja sama regional.
\end{abstract}

Kata kunci: Asia Tengah, Belt and Road Initiative, Regionalisme, Kerja Sama Regional.

\section{Introduction}

In 2013, Xi Jinping announced the born of China's ambitious foreign policy and economic initiatives, One Belt, One Road (OBOR) on his visit to Kazakhstan and Indonesia. OBOR will create an infrastructure building to connect China all the way to Europe. He said that OBOR will be $21^{\text {st }}$ century of Silk Road Economic Belt (SREB) and Maritime Silk Road (MSR). The Silk Road will connect China to Europe through Central Asian, while the Maritime Silk Road will connect China to Europe through the Southeast Asian region.

Though known as OBOR, in 2016 China renamed the English name of her initiatives to Belt and Road Initiative. China saw the OBOR could be misleading, as the word "One" may lead to people misinterpretation as people might be assuming there will only be one 
maritime road and one silk-road. Therefore, in 2017, he launched the Belt and Road Initiative that will connect Asia, Africa, and Europe continent.

With their abundance reserve of energy, vast raw material resources, geo-strategic position, Central Asia hold an important role in realizing the BRI. Central Asia region is still adjusting to their new status as sovereign states. After their independence from the Soviet Union in 1991, Central Asia nations - Kazakhstan, Uzbekistan, Kyrgyzstan, Tajikistan, and Turkmenistan - are still facing the problem of political turmoil within their country and region. The 1992 - 1997 civil wars in Tajikistan, the 2005 violence in Uzbekistan, 2005 Tulip Revolution in Kyrgyzstan, and leadership changes in Turkmenistan and Uzbekistan in 1992 and 2016. ${ }^{1}$ The trend towards separation and integration is clearly shown in the region and reinforced by the competition for the same market and for catching the attention of external players. The Central Asia nations also developed closed political entities, and sometimes hostile to the neighbors to the point that they build alternatives road to avoid passing through the territory of unfriendly neighbor. The socio-economic challenge also remains the biggest threats to Central Asia's stability. Disruptions on the management of water and energy have created more tension and problem within the region and could be a resource of potential conflict. ${ }^{2}$

Lack of regional integration is one of the presumable assumptions on the instability of the Central Asia region. Despite the shared history and being referred as a single region, the countries have a different level of political - economic development, cultural and ethnic composition, and relations within the region and with other actors in the world. Numerous regional cooperation such as Shanghai Cooperation Organization (SCO), Commonwealth of Independence State (CIS), Eurasian Economic Community (EEC) remained stagnant. With the presence of BRI as an external factor, there might be a possibility for further integration in the region.

This paper aims to explain regionalism in Central Asia with the presence of BRI. This paper is trying to answer the question to what extent that BRI can be a catalyst for further regionalism within the Central Asia region. This paper will be divided into three parts. First, it will explain about the clash of identity in regional cooperation and regional

\footnotetext{
${ }^{1}$ Llyod Alexander M. Adducul, "Central Asia and the Belt and Road Initiative: Cosideration for the Philippines," Center for International Relations and Strategic Studies V, no. 2 (2018): 1. 2 ibid
} 
integration in Central Asia. Second, it will explain the impact of BRI on the regional integration in Central Asia. Lastly, it will explain about the conclusion.

\section{Regionalism in Central Asia: Clash of Identity}

Regionalism is defined as a state-led or states-led project designed to re-organize a particular regional space along defined economic and political lines. Regionalism covers both regional integration and regional cooperation. Regional cooperation and regional integration are terms that often used synonymously, but they are actually different. The former often encompasses policies and agreements related to removing trade barriers, economic partnership, or cooperation for investment. On the other hand, regional integration means a deeper form of cooperation that could include an alignment of customs regimes, cross-border connectivity, communication, and energy-related linkages. ${ }^{3}$

Processes of regional integration are driven by people with a national or regional background and affect people that are the citizen from existing nations. The process of regional integration and identity construction can be mutually influential. Changes in governance can lead to changes in how people perceive themselves and the changes in identity construction can promote new conceptions on how people govern 'themselves' and who they are. ${ }^{4}$

The Central Asian nations are a new phenomenon in terms of nation-statehood. Before the Soviet Union established them as a distinct national territorial unit, Central Asia exist not as modern, sovereign, independent states as understood in the Westphalian sense of state. From the historical perspective, Central Asia is more used to the religious or ethnic identity instead of their national identity. In the $19^{\text {th }}$ Century, Central Asia nations have preferred to use the Arabic term of 'millat' that related to the religious community instead of the Russian term of 'natsiya' which mean nation. ${ }^{5}$

In 1924, when the Soviet Union and autonomous republic were created, contemporary artificial borders of ethnic communities were established. With the help of

\footnotetext{
${ }^{3}$ Andrew Gamble, Anthony Payne, Regionalism and World Order, London: Mcmillan, 1996, 20

${ }^{4}$ Nikki Slocum, Luk Van Lagenhove, "Identity and Regional Integration," Global Politics of Regionalism: Theory and Practice, (Chicago: Pluto Book, 2005): 19.

${ }^{5}$ Rico Isaacs, Abel Polese, "Between 'imagined' and 'real' nation-building: identities and nationhood in postSoviet Central Asia,” Nationalities Papers 43 no.3, (2015): 372.
} 
ethnographers, linguist and assisted by indigenous communist, the Soviet authorities dissolved the region's multiethnic political entities and created the new 'national' republics, each named for a single ethnic group. After the number of boundary shift and adjustment, the final result was the map of Central Asia we see today, with the five national republics of Uzbekistan, Turkmenistan, Tajikistan, Kazakhstan, and Kyrgyzstan. ${ }^{6}$

Because of the religious and ethnic identity that tied with the people of Central Asia nations, the Soviet Union authorities had to impose social contradictions along the process of the Soviet social system formation in Central Asia. The authorities took it upon themselves to become 'nation-makers' in the region, institutionalizing, and ascribing the borders and ethnic categories that became the basis for post-Soviet nation-statehood. ${ }^{7}$ The Soviet authorities then develop the education in local language and built standards based on minority languages and had set the boundaries of Central Asian nations and ethnic groups. Having a close tied to their religious and ethnic identity as well as the identity that is imposed by 'other', it is no wonder that the nationalism of Central Asian nations took another character, one that not opposing the Soviet system, but pitting other ethnic groups against another. And this is the reason for several outbreaks of violence targeting minorities like one that happened in 2010 between Kyrgyz and Uzbek in Kyrgyzstan.

The break-up of the Soviet Union is the turning point for the Central Asian nations to finally develop their own national identity, one that differed from their religious and ethnic communities. The process of nation-building for them is very fundamental just like the political, economic, and social reform. The Central Asian leaders decided to step up and focus on their internal policy and strengthening the national institution. However, their authoritarianism government does not really help. The leader of the Central Asian had to impose the 'identity' with the one that they perceived. This top-down approach does not help because when we talk about Central Asia, each nation has different kinds of ethnicity due to the massive migration within the Soviet nations and often it clashed with the way the leaders want the nationalism would be. Because when we talked about creating a national identity, there will be fundamental distinction between one that created by the government with the one initiated by the society. ${ }^{8}$

\footnotetext{
${ }^{6}$ Adrienne L. Edgar, "Identities, Communities, and Nations in Central Asia: A Historical Perspective," Central Asia and Russia to the 'War on Terrorism presentation on University of California Berkley. (2001): 4.

${ }^{7}$ Isaac and Polese, 375.

8 Pinar Akcali, "Nation-State Bulding in Central Asia: A Lost Case?" Perspective on Global Development and Technologi 2, no. 4 (2003): 410.
} 
If national identity building in Central Asian nations fail then what about the regional identity building? Much to our regret, it remained the same as the former. Since the 1990s, the leader of the Central Asian nations has met to discussed about creating a regional cooperation, one without the presence of Russia or China. However, the result is not what they and the rest of the world expected. The borders problems of demarcation, uncontrolled borders crossing and territorial claiming not only coming from the neighboring countries but also among themselves. Turkmen - Uzbek, Uzbek - Kazakh, Uzbek - Tajik, Uzbek - Kyrgyz and Kyrgyz - Tajik border are still disputed. ${ }^{9}$

Several regional cooperation in Central Asia like Commonwealth of Independence States (CIS), Shanghai Cooperation Organization (SCO), Organization Security and Cooperation in Europe (OSCE) and Central Asian Cooperation Union (CACO) failed to accommodate the needs of the countries within the region. Most of the organization offered the same approach for problems happening in Central Asia. This does not help because Central Asia is very different, despite the shared culture, history, and language. In the case of OSCE, the failure is due to the inability for OSCE to develop a political strategy because the participating countries have different ideas of what they expect the organization to do. While in the case of CIS, attempted to foster cooperation failed due to the differences that resulted in a large number of unfulfilled agreements. This unfulfilled agreement then resulted in resentment from the member, including the Central Asia member. ${ }^{10}$

The organizations originated within the region had few incentives. While the weaker state has been enthusiastic about the potential benefit, the stronger one saw them as the matter of prestige and as an opportunity to promote themselves in the role of regional leader, and did not see the cooperation as a problem-solving tools. Dr. Thortsten Bonacker once said that, the problem within the Central Asia regions is the fact that the region is lacking in the sense of belonging and how to identify themselves, either from within or without.

"For me, the term of Central Asian region comes from the outside. In particular, Europeans see the post-Soviet republics as a single region.

\footnotetext{
${ }^{9}$ Pinar Akcali, 420.

10 Anna Matveeva, "The regionalist project in Central Asia: Unwilling Playmates," Crisis States Research Institute London School of Economic working paper no.13 (2007): 10.
} 
However, the Central Asian countries do not perceive themselves necessary as part of a single or integral region." 11

The Central Asian nations do not perceive themselves to be part of a single or integral region, thus the integration among the five nations is very hard to achieve. They only think about their country and trying to solve the problems that have spill-over effect on other countries, by themselves, instead of looking for a comprehensive approach that involved other countries within the region.

\section{BRI and Regionalism: Connecting the Dot}

BRI is neither institution nor organization. It is an economic initiative aims to promote connectivity, trade, financial integration, and policy coordination. Compared to regional organization or regional trade agreements, BRI focuses more on improving physical connectivity rather than reducing institutional barriers. Physical connectivity is very important for developing countries with poor infrastructure as it could boost trade and commerce, easing flows of energy and other resources, stimulating technological innovation, influencing culture and politics, and shaping strategic choices.

Many scholars in International Relations have been discussing the similarity between BRI and regionalism. Andreas Grimmel and Yuan Li identify BRI as a hybrid model of regionalism that consist of EU-type of old regionalism and new regionalist projects. The term old-regionalism referred to the initiatives that originated in Western Europe after the end of the Second World War. Old regionalism is shaped by the bipolar setting of world politics which is dominated by rivalry instead of cooperation. Therefore, old regionalism focuses on overcoming the 'lust of power' and created a peaceful and prosperous political system. New regionalism, on the other hand, took shape in the multipolar world order and in a context of globalization. In the new regionalism, the non-state actor is considered to be playing role in influencing the regional cooperation and integration as the new regionalism is constructed by globalization. New regionalism believes that regional cooperation is not only seen in the organization or institution. ${ }^{12}$

\footnotetext{
11"Regional Conflicts in Central Asia: Issues of Identity and EU Experience," Central Asian Bureau for Analytical Reporting. Accessed 5 November 2018, https://cabar.asia/en/.

12 Frederick Soderbaum, Bjorn Hettne, "The Future of Regionalism: Old Divides, New Frontiers," in Regionalization and Global Governance: the Taming of Globalization, (London: Routledge, 2008): 70.
} 
For Xi Jinping, BRI will deepen cooperation and improve development space in the Eurasian region. BRI will focus to promote connectivity in different regions in Asia, Europe, and Africa. ${ }^{13}$ The document also mentions about the objectives of BRI which is promoting orderly and free flow of economic factors, highly efficient allocation of resources and deep integration of markets, and creating open, inclusive, and balanced regional economic cooperation that benefits all.

Connecting all the dots, BRI can be described as a regionalism project. BRI have objectives that are sought by the regionalism which is finding a way for global economic growth, realizing global rebalancing, and creating a new model for regional cooperation. ${ }^{14}$ Grimmel and $\mathrm{Li}$ also mentioned three features of characteristic for a regionalism project that can be found as a part of BRI: a general emphasis of non-interference as the basic common action, an institutional minimalism and non-bindingness of common decision, a principles of pragmatism and flexibility, and a high degree of political and economic heterogeneity of member states and low hurdles for the participation in the regionalism project. ${ }^{15}$ In the long term, BRI aims to achieve a region of harmony, peace, and prosperity. The objectives that are sought by BRI match with the goals sought by regionalism.

BRI can be seen through the neo-functionalism theory. Neo-functionalism describes the process of regional integration through three factors: 1. Growing economic interdependence between nations, 2. Organization capacity to resolve disputes and build international regimes, 3. Supranational market rules that replace national regulatory regimes. China is trying to grow the interdependence between the BRI partner members along the new Silk Road. The dream of achieving the region of prosperity, harmony, and peace is seen as a way to build international regimes. One of neo-functionalism theory is about positive spillover effects, a concept about how integration between states in a particular sector will create strong incentive for integration in further sectors. Some scholars have been stating that BRI is a way China develops its neo-functionalist

\footnotetext{
${ }^{13}$ According to the "Vision and Actions on Jointly Building Silk Road Economic Belt and $21^{\text {st }}$ Century Maritime Silk Road" issued by the National Development and Reform Commission, Ministry of Foreign Affairs and Ministry of Commerce China.

${ }^{14}$ Luk Van Langehove, and Danielle Marchesi, "The Treaty of Lisbon and the Emergence of Third Generation Regional Integration," European Journal of Law Reform 10, no. 4 (2008): 482

${ }^{15}$ Andrea Grimmel, Yuan Li, "The Belt and Road Initiative: a Hybrid Model of Regionalism," Working Paper on East Asian Studies no.122, 2018:9
} 
approach to global affairs and also try to employ the spillover logic: China trust that the closer economic ties generated by BRI will spill over into closer political ties. ${ }^{16}$

\section{BRI and Its Impact on Central Asia Regional Integration}

As an economic initiative, it is undoubtedly that BRI will bring so many impacts to its partners. In particular to Central Asia, much research has been done to look for the impacts BRI will have on the region, ranging from economic development to governmental reform. In this paper, the writer will highlight three points of BRI impacts on Central Asia, which is economic development, institutional reform, and creating a new regional identity.

As has been said before, the BRI present an initiative that will help the region to develop their infrastructure. So far, three railroad connections in the region have been completed under the BRI banner: Pop-Angren in Uzbekistan, Uzen-BereketGorgan traversing Kazakhstan, Turkmenistan, and Iran, and Khorgos dry port in Kazakhstan that connects China and Kazakhstan. Boosting these factors is very important as Central Asia nations have been suffering from poor infrastructure that hampers trade growth in Central Asia.

One of the obstacles for cooperation within the five nations is a huge power and economic imbalance between countries, a quest to entrench sovereignty, political grievances among the leaders and mutual suspicion of security threats emanating from neighbors. The leader of the countries would rather have their own statehood to be firmly entrenched than to engage in regional cooperation. ${ }^{17}$ As for the economic imbalances, economic development of the Central Asian countries is not equal. Kazakhstan is the most developed, having GDP per capita of $\$ 8.800$ while Kyrgyzstan is the poorest with GDP per capita of $\$ 1.110$. $^{18}$

\footnotetext{
${ }^{16}$ William A. Callahan, "China's Belt and Road Initiative and The New Eurasian Order," Norwegian Institute of International Affairs, 22 March 2016, accessed 7 November 2018, https://brage.bibsys.no/xmlui/bitstream/handle/11250/2401876/NUPI_Policy_Brief_22-

16_William_Callahan.pdf.

${ }^{17}$ Anna Matveeva, 4.

18 "Data for Europe \& Central Asia, Kazakhstan, Kyrgyz Republic 2016," The World Bank, accessed 7 November 2018. https://data.worldbank.org/?locations=Z7-KZ-KG
} 


\section{Institutional Reform}

Central Asian countries are faced with isolationist, protectionist trade and transit agreement that causes the poorly harmonized trade, investment, and border crossing procedures. ${ }^{19}$ The region also faced with lack of transparency in the government that resulted in numerous corruptions happening within the internal institution. In 2017, All the Central Asian countries rank is under the 120 for in the corruption perceptions index. Kazakhstan rank 120, Kyrgyzstan in 135, Uzbekistan in 157, Tajikistan in 161, and Turkmenistan $167 .^{20}$

The possibility of economic development under the initiatives is feasible. However, in order to make that happen, institutional reform and strong political commitment are needed to overcome the problems of corruption, vested interest, liberalize border, trade, and investment. A stable institutional and business climate is needed to make the best of BRI benefits. Central Asian countries are expected to improve the business environment, creating a liberal and internationally complaint trade policy, a joint approach to managing the cross-border procedures, and addressing the problem of informal barriers and payments for cross-border. ${ }^{21}$

Included in the vision and actions on jointly building Belt and Road, one of the cooperation priorities is the policy coordination. Enhancing spolicy coordination is important to implement the initiative. BRI promotes the idea of transparency and coordination of intergovernmental cooperation, multi-level intergovernmental macro policy exchange, expand shared interest, enhance mutual political trust, and reach new cooperation consensus. ${ }^{22}$ In another hand, BRI might force the Central Asian countries to reform their institution in order to be able to engage with the BRI and benefited from them.

\footnotetext{
${ }^{19}$ Sobir Korbanov, "The Importance of Anticurroption, Trade, and Investment Climate Reforms in Central Asia in the Context of BRI." In China's Belt and Road Inititative and Its Impact in Central Asia, edited by Marlene Laurelle (Washington: The George Washington University, 2018), 86.

20 "Corruption Perception Index 2017," Transparency International, diakses 7 November 2018, https://www.transparency.org/news/feature/corruption_perceptions_index_2017.

${ }^{21}$ Korbanov, 93.

22 "Full text: Vision and actions on jointly building Belt and Road," Xinhua News, 28 March 2015, accessed 7 November 2018, http://www.xinhuanet.com//english/china/2015-03/28/c_134105858_3.htm.
} 
Jurnal Sentris KSMPMI Vol. 1 - 2019

\section{Economic Development}

Improved infrastructure can be a catalyst for employment and economic growth. China investments are aims to build up local industry and diversify Central Asia economies. In the case of trade, BRI may influence the growth of foreign trade within the region through several channels: 1) developing transport infrastructures facilitating trade of Central Asia region to/from China, Europe, and West Asia, 2) development of other infrastructure such as electricity, irrigation system, product quality testing, and others to lower production cost and export cost, 3) cooperation in trade policy and trade facilitation.

The BRI provides opportunities for Central Asian countries to develop and expand their trade relations with another region, in particular China. ${ }^{23}$ Having a rail connection between the trading partners has an impact to improve trade by $2.8 \%$ in the export area. ${ }^{24}$ Improvement of economic development to all the 5 nations of Central Asia might have the possibilities to overcome the imbalance and improve economic integration in the region. If institutional reform within the government of the Central Asian countries did happen, then it would make doing business in the country easier. It will also open a public-private partnership, access to the new market, and creating a selfentrepreneurship. $^{25}$

\section{Creating New Regional Identity}

BRI might also help to forge the new regional identity in Central Asia. According to Annsi Paasi, regional identity is a key element in the making of regions as social and political spaces. Regional identity is a process consisting of the production of territorial boundaries, symbolism, and institution. ${ }^{26}$ In some cases, regional identities are forged through the outside-in process.

\footnotetext{
${ }^{23}$ Roman Mogilevski, "Possible Impacts of the Belt and Road Initiative on Foreign Trade in Central Asia." Center for Social and Economic Research, 22 January 2018, https://medium.com/@CASEresearch/possibleimpact-of-the-belt-and-road-initiative-on-foreign-trade-in-central-asia-f67e504b3fa9.

24 "The Economics Effects of Improved Transport Links in Belt and Road Initiative," World Economic Forum, 20 September 2018, accessed 7 November 2018, https://www.weforum.org/agenda/2018/09/measuring-theeconomic-impact-of-improved-transport-links-in-belt-and-road-countries.

${ }^{25}$ Ibid.

${ }^{26}$ Aansi Paasi, “The Resurgence of the 'Region' and 'Regional Identity': Theoretical Perspective and Empirical Observations on Regional Dynamics in Europe,” Review of International Studies 35, (2009): 136.
} 
Central Asia is a regional concept that is a historically imported concept, where external actors identify it with authoritarianism, terrorism, ethnic violence, and political instability. The region is a clear example of outside-in approach to identify region by the means of powerful states purposes and interest. ${ }^{27}$ In the case of BRI and Central Asia, the region would prefer to be perceived from the outside as parts of the dynamic space of the BRI, and thus acquire new clean regional identity. ${ }^{28}$ And with the new clean regional identity, the Central Asia countries will have the opportunity to engage in political, economic, and development with each other, creating a possibility of improving the current Central Asian regional cooperation such as CIS and SCO.

The institutional reform, economic development, and creating new regional identity might have the possibility to further develop the integration of the Central Asian nations. The document of the vision and actions on jointly building Belt and Road mentions the mechanism for realization of BRI which includes the role of regional cooperation such as SCO, ASEAN, APEC, ASEM, and CAREC. And among them is the regional cooperation that was joined by the Central Asia nations such as SCO and CAREC. The success of BRI will increase the importance of several Eurasian and Asian regional organizations as regional actors in today's politic and the possibility for the Central Asian nations to be benefited from the increasing importance and to be further engaged within the organization. Therefore, BRI is seen to be more feasible in promoting regional integration within the Central Asia nations.

\section{Conclusion}

BRI and Central Asia is a topic that has been buzzing between the international relations scholars. Research has been conducted to see the benefits of BRI to the Central Asia regions. In this paper, the writer tried to look for the answer whether or not BRI can be a catalyst for regional integration in Central Asia. Even though BRI is not an institution or organization, the objectives of the initiative match well with the regionalism, making it perceived by others as a regionalism project. In the era of globalization, regionalism doesn't always come from institution, organization, or

\footnotetext{
${ }^{27}$ Ikboljon Qoraboyev, "One Belt, One Road: Comparative Regionalism Approach," in The Belt and Road Initiative in the Global Arena: China and European Perspectives, ed. Cheng Yu (London: Palgrave Macmillan, 2018), 111.

${ }^{28}$ Ibid.
} 
agreement and the topics are not limited to political, economic, or security. According to the logic of spillover from the neo-functionalist theory, China is trying to employ the spillover logic: China trust that the closer economic ties generated by BRI will spill over into closer political ties.

As we can see, the initiatives are not only focused on political and economic, but also in culture. BRI aims to connect and integrates the Asia, African, and Europe region with the long-term aims of achieving a region of prosperity, harmony, and peace. The impact of BRI to the Central Asia regions is not limited to economic development, but also institutional or governmental reforms. The infrastructure building by the BRI might help in boosting economic growth and trade as it has been mentioned that infrastructure is very important to improve development and economy. BRI also helping Central Asia to combats corruption and institutional reform, as the participating countries are force to overcome problems that will hamper the country to be benefited from the initiatives. And last but not least, BRI might also influence the creation of a new identity for the region. Central Asia can get new clean identities from the BRI and leaves the old regional identity that is perceived by other actors as a region of authoritarianism, terrorism, and ethnic violence. All of these can contribute to the improvement of integration within the Central Asian nations. To conclude this paper, the BRI have the possibility to be a catalyst for regional integration in Central Asia. 


\section{Bibliography}

Adducul, Llyod Alexander M. "Central Asia and the Belt and Road Initiative: Cosideration for the Philippines." Center for International Relations and Strategic Studies V, no. 2 (2018): 1 - 24.

Akcali, Pinar. "Nation-State Bulding in Central Asia: A Lost Case?" Perspective on Global Development and Technology 2, no.4 (2003): 390 - 420.

Callahan, William A. “China's Belt and Road Initiative and The New Eurasian

Order. Norwegian Institute of International Affairs. 22 March 2016. Accessed 7

November 2018.

https://brage.bibsys.no/xmlui/bitstream/handle/11250/2401876/NUPI_Policy_Brief_2

2-16_William_Callahan.pdf.

Edgar, Adrienne L. "Identities, Communities, and Nations in Central Asia: A Historical Perspective. "Central Asia and Russia to the 'War on Terrorism presentation on University of California Berkley. 2001.

Gamble, Andrew, Anthony Payne. Regionalism and World Order, London: Mcmillan, 1996.

Grimmel, Andrea and Yuan Li, "The Belt and Road Initiative: a Hybrid Model of Regionalism.” Working Paper on East Asian Studies no.122, (2018): 1- 22.

Isaacs, Rico and Abel Polese. "Between 'imagined' and 'real' nation-building: identities and nationhood in post-Soviet Central Asia." Nationalities Papers 43 no.3, (2015): 371 382.

Korbanov, Sobir. "The Importance of Anticurroption, Trade, and Investment Climate Reforms in Central Asia in the Context of BRI." In China's Belt and Road Inititative and Its Impact in Central Asia, edited by Marlene Laurelle, 86 - 96. Washington: The George Washington University, 2018.

Matveeva, Anna. "The regionalist project in Central Asia: Unwilling Playmates." Crisis States Research Institute London School of Economic Working Paper no.13, (2007): $1-22$.

Mogilevski, Roman. "Possible Impacts of the Belt and Road Initiative on Foreign Trade in Central Asia." Center for Social and Economic Research. 22 January 2018. Accessed 
in $\quad$ https://medium.com/@CASEresearch/possible-impact-of-the-belt-and-roadinitiative-on-foreign-trade-in-central-asia-f67e504b3fa9.

Paasi, Aansi. “The Resurgence of the 'Region' and 'Regional Identity': Theoretical Perspective and Empirical Observations on Regional Dynamics in Europe." Review of International Studies 35, (2009): 121 - 146.

Qoraboyev, Ikboljon. “One Belt, One Road: Comparative Regionalism Approach.” in The Belt and Road Initiative in the Global Arena: China and European Perspectives, ed. Cheng Yu. London: Palgrave Macmillan, 2018.

Slocum, Nikki and Luk Van Lagenhove. "Identity and Regional Integration." Global Politics of Regionalism: Theory and Practice. Chicago: Pluto Books: 2005.

Soderbaum, Frederick and Bjorn Hettne. "The Future of Regionalism: Old Divides, New Frontiers". In Regionalization and Global Governance: the Taming of Globalization. London: Routledge, 2008.

Van Langenhove, L. and Danielle Marchesi. "The Lisbon Treaty and the emergence of third generation regional integration.” European Journal of Law Reform 10, no.4 (2008): $477-496$.

"Data for Europe \& Central Asia, Kazakhstan, Kyrgyz Republic 2016." The World Bank. Accessed 7 November 2018. https://data.worldbank.org/?locations=Z7-KZ-KG

“Corruption Perception Index 2017." Transparency International. Accessed 7 November 2018.https://www.transparency.org/news/feature/corruption_perceptions_index_2017.

"Full text: Vision and actions on jointly building Belt and Road." Xinhua News. 28 March 2015, Accessed 7 November 2018. http://www.xinhuanet.com//english/china/201503/28/c_134105858_3.htm.

"Regional Conflicts in Central Asia: Issues of Identity and EU Experience." Central Asian Bureau for Analytical Reporting, Accessed 5 November 2018. https://cabar.asia/en/.

“The Economics Effects of Improved Transport Links in Belt and Road Initiative." World Economic Forum, 20 September 2018. Accessed 7 November 2018. https://www.weforum.org/agenda/2018/09/measuring-the-economic-impact-ofimproved-transport-links-in-belt-and-road-countries. 